\title{
The dynamics of ${ }^{60} \mathrm{Co}$ - labelled sediment particles in the Seine estuary
}

\author{
D. Boust, P. Lesueur', M. Rozet, L. Solier and A. Ficht ${ }^{2}$ \\ Laboratoire d'Études Radioécologiques de la Façade Atlantique, IPSN, Octeville, France \\ ${ }^{1}$ Laboratoire Morphodynamique Continentale et Côtière, \\ UPRES A 6143 du CNRS, Université de Caen, France \\ ${ }^{2}$ Service de la Navigation de la Seine, Port Autonome de Rouen, France
}

\begin{abstract}
From 1990 to $2000,{ }^{60} \mathrm{Co}$, a radionuclide released into the English Channel by the La Hague reprocessing plant, has been measured in the deposited sediments of the Seine estuary. Since 1990 , the ${ }^{60} \mathrm{Co}$ concentrations have slowly increased from some tenths of $\mathrm{Bq} \cdot \mathrm{kg}^{-1}$ to $\mathrm{ca} 10 \mathrm{~Bq} \cdot \mathrm{kg}^{-1}$. This transient signal was used to bring the evidence of the input of marine particles far upstream in the estuary, $c a 80 \mathrm{~km}$ from the river mouth. The dynamics of this process have been deciphered by comparing several sets of data obtained in the years 1990 to 2000 . An average velocity of about $10 \mathrm{~km}^{-y^{-1}}$ was found for this incoming sediment pool. These observations are conformable with calculated of suspended sediment fluxes performed along the river.
\end{abstract}

Knowledge of particulate transport processes is a key issue in estuarine systems. As a matter of fact, sediment particles are the vectors of a variety of chemical and bacteriological contaminants. In the Seine estuary, $\gamma$-emitting radionuclides were used as particle tracers to study mixing processes between marine and riverine particles. These field studies yielded an unexpected result: inflow of marine particles far upstream from the river mouth.

\section{ENVIRONMENTAL SETTINGS}

The Seine river is the unique outlet of a drainage basin having a surface area of $78000 \mathrm{~km}^{2}$ and is home of $30 \%$ of the population of France and $40 \%$ of the country's economic activity. The Seine estuary (Fig. 1) undergoes a macrotidal regime, the consequences of which are following:

- the saline water penetrates the estuarine system upstream from Tancarville (kp 338; the reference kilometric point, $\mathrm{kp} 0$, is at the Pont Marie in Paris);

- the tidal wave propagates up to the Dam of Poses (kp 202.2) which stops any tidal influence further upstream ; consequently, estuarine water oscillates upstream and downstream with a semidiurnal periodicity (ebb and flood) and the tidal range (difference between high and low tide levels) can reach $1 \mathrm{~m}$ at Poses and up to $8 \mathrm{~m}$ at the river mouth (Le Havre) during spring tidal period.

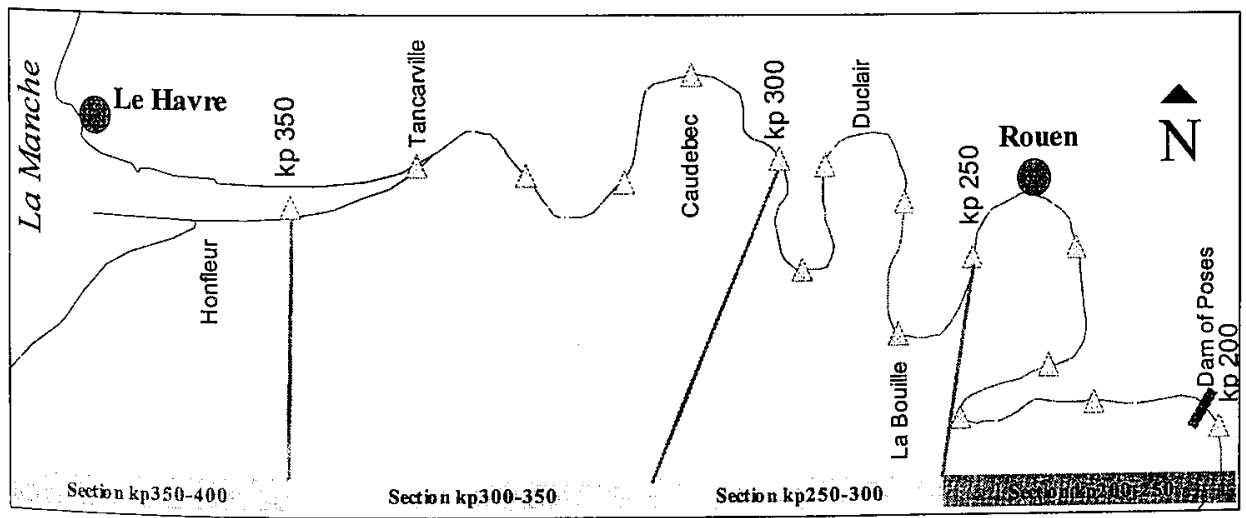

Figure 1. Map of the study area; triangles represent $10 \mathrm{~km}$-spaced kilometric points. 


\section{SOURCES OF ARTIFICIAL RADIONUCLIDES IN THE SEINE ESTUARY}

Cobalt $60\left({ }^{60} \mathrm{Co}\right)$ and caesium $\left({ }^{137} \mathrm{Cs}\right)$ are two of the most commonly encountered artificial radionuclides in the sediments of the study area. ${ }^{137} \mathrm{Cs}$ mainly originates from global fallout and nuclear plants; it is introduced in the estuary from both the Seine catchment area and the English Channel [1]. ${ }^{60} \mathrm{Co}$ comes from the controlled releases of the La Hague reprocessing plant (French coast) and the nuclear plant at Winfrith (now stopped; English coast) in the Central Channel [1]. ${ }^{60} \mathrm{Co}$ is also released into the Seine river by the nuclear power plant at Nogent (upstream from Paris); the ${ }^{60} \mathrm{Co}$ amounts are not likely to yield detectable concentrations in sediments deposited downstream from Poses (Bonté, pers. com.), except in the close vicinity of the outfall of the nuclear power plant at Nogent-sur-Seine [2].

\section{THE INVASION OF THE SEINE ESTUARY BY ${ }^{60} \mathrm{Co}$ LABELLED SEDIMENT PARTICLES IN THE YEARS 1990 TO 2000}

${ }^{60} \mathrm{Co}$ and ${ }^{137} \mathrm{Cs}$ have been measured in surface sediments exposed above the waterline at low tide between Poses Dam and Honfleur (kp 354), and collected by hand; further downstream, sediment samples were recovered using Shipeck grab. Specific activities range between $0.5-10 \mathrm{~Bq} \cdot \mathrm{kg}^{-1}$ and $\mathrm{l}$. $20 \mathrm{~Bq} \cdot \mathrm{kg}^{-1}$, for ${ }^{60} \mathrm{Co}$ and ${ }^{137} \mathrm{Cs}$, respectively [3-5]. The data are presented as ${ }^{60} \mathrm{Co} /{ }^{137} \mathrm{Cs}$ activity ratios normalized to a unique reference date: $01 / 01 / 2000$ (Fig.2). Therefore, ${ }^{60} \mathrm{Co} /{ }^{137} \mathrm{Cs}$ normalized activity ratios can be compared for various sampling periods and data scattering due to granulometric effects can be overcome. On figure $2,{ }^{60} \mathrm{Co} /{ }^{137} \mathrm{Cs}$ normalized ratios obtained during sampling campaigns between 1990 and 2000, have been plotted versus distance in the Seine estuary (with reference to $\mathrm{kp} 0$ in Paris).

In 1990 , no ${ }^{60} \mathrm{Co}$ was found upstream $\mathrm{kp} \mathrm{315}$, in spite of numerous measurements carried out between $\mathrm{kp} 315$ and 200. In 1993, this pattern is confirmed and a downstream increase of the ${ }^{60} \mathrm{Co} /{ }^{137} \mathrm{Cs}$ ratios appears. In the $1993-95$ period, a general increase of ${ }^{60} \mathrm{Co} /{ }^{137} \mathrm{Cs}$ ratios is observed at every point downstream from $\mathrm{kp} 310$. This trend is going on in 1997; furthermore, ${ }^{60} \mathrm{Co}$ is detected in surface sediments as far from the river mouth as $\mathrm{kp} \mathrm{283,} \mathrm{that} \mathrm{is} \mathrm{to} \mathrm{say} \mathrm{ca} 100 \mathrm{~km}$ upstream from the open sea. The pattern is further completed by the evidence of ${ }^{60} \mathrm{Co}$ into suspended particles collected at La Bouille (kp 260) and Rouen (kp 243) in 1996 and 1998, respectively. In the lowest (and better documented) sections of the estuary (kp 350-400; kp 300. $350),{ }^{60} \mathrm{Co} /{ }^{137} \mathrm{Cs}$ values continuously increase with time, reaching values as high as 1.1 . This observation can be more clearly performed on figure 3 which displays ${ }^{60} \mathrm{Co} /{ }^{137} \mathrm{Cs}$ ratios versus time in four $50 \mathrm{~km}$ long section of the estuary.

This data set is likely to be interpreted as the result of the inflow of ${ }^{60} \mathrm{Co}$ labelled sediment particles from the sea to the estuary and their subsequent mixing with riverine particles devoid of ${ }^{60} \mathrm{Co}$. Data scattering is due to the fact that, at a given point, more recent ${ }^{60} \mathrm{Co}$ labelled sediment pools are liable to mix up with "older", e.g. more ${ }^{60} \mathrm{Co}$ depleted sediment particles, yielding lower ${ }^{60} \mathrm{Co} /{ }^{137} \mathrm{Cs}$ ratios. This scenario is highly consistent with the history of the input of ${ }^{60} \mathrm{Co}$ labelled particles in the Central Channel (see Section 4). As the input of ${ }^{137} \mathrm{Cs}$ from the Seine river cannot be neglected, the ${ }^{60} \mathrm{Co} /{ }^{137} \mathrm{Cs}$ ratios can only be used qualitatively at this stage and no sediment mixing ratio can be derived. Nevertheless, careful inspection of the data yields an average velocity of $c a 10$ km. $\mathrm{y}^{-1}$ for the ${ }^{60} \mathrm{Co} /{ }^{137} \mathrm{Cs}$ transient signal. 

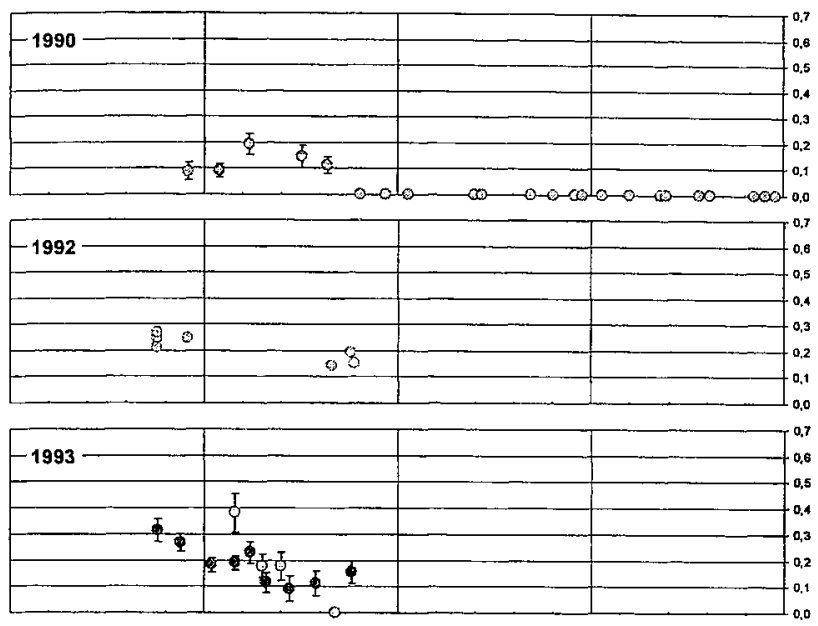

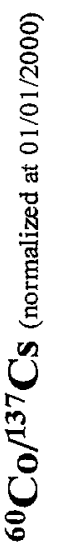
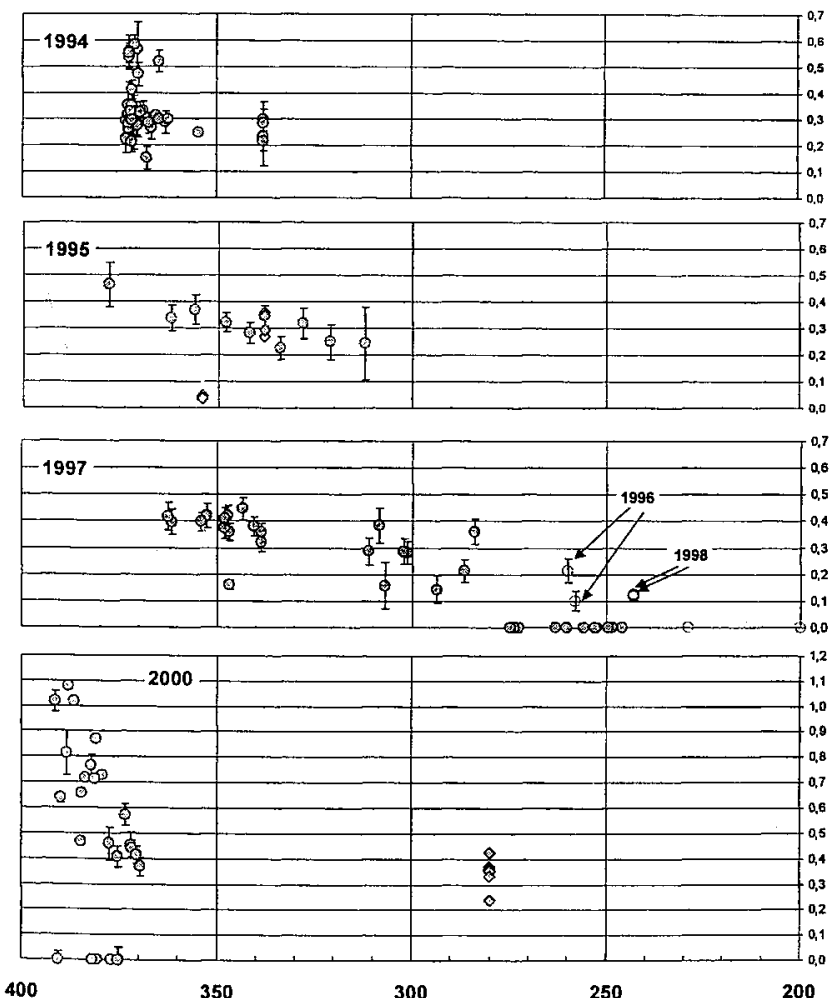

Distance from Paris (km)

Figure 2. The ${ }^{60} \mathrm{Co} /{ }^{137} \mathrm{Cs}$ activity ratios (normalized at $01 / 01 / 200$ ) in surface sediments plotted versus distance in the Seine estuary between 1990 and 2000; samples labelled 1996 and 1998 on the 1997 graph represent suspended material; samples plotted as diamonds represent cored sediment from a mudflat: at kp 340 and 355 , in 1995 and at $\mathrm{kp} 280$ in 2000 ; note that the y extend is the same for all graphs except for the graph of year
2000. 


\section{GOING FURTHER IN SIGNAL RECONSTRUCTION}

The history of the ${ }^{60} \mathrm{Co} /{ }^{137} \mathrm{Cs}$ ratio can be further reconstructed using radionuclide measurements performed on a sediment core (average sedimentation rate $=14,5 \mathrm{~cm} . \mathrm{y}^{-1}$ ) collected in the vicinity of Le Havre (kp 365) in 1992. The data are shown on figure 4 together with an additional data set obtained in sediment cores collected in the Roads of Cherbourg (Central Channel), $140 \mathrm{~km}$ westwards, in which reliable estimations of the sedimentation rates were obtained by ${ }^{210} \mathrm{~Pb}$ excess measurements. The ${ }^{60} \mathrm{Co} /{ }^{137} \mathrm{Cs}$ history observed in Central Channel and in the Seine estuary are clearly reminiscent of each other. This strongly suggests an eastward migration of ${ }^{60} \mathrm{Co}$ labelled particles from the Central Channel to the Seine estuary as a consequence of bed load transport across the Bay of Seine. Comparison of the two time-series suggests that such eastward drift of sediment particles takes about 10 years from Cherbourg area to the Seine estuary. This average transit time is consistent with previous estimations based on plutonium isotopes [6].
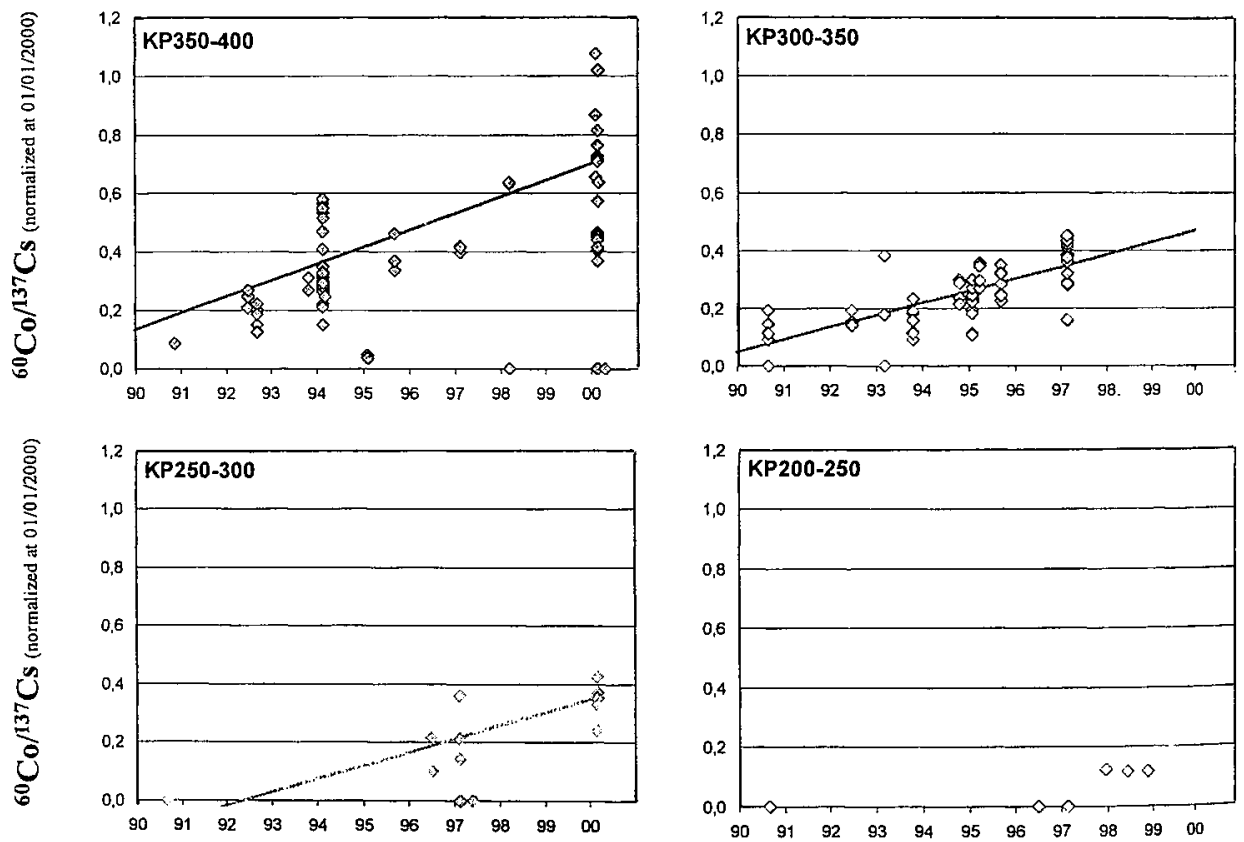

Figure 3. Evolution of ${ }^{60} \mathrm{Co} /{ }^{137} \mathrm{Cs}$ ratios in surface sediments versus time (years) in four $50 \mathrm{~km}$ long sections of the estuary (see figure 1).

\section{UNVEILING THE PARADOX}

How can sediment particles progress upstream? Of course, upstream does not mean at countercurrent. This intriguing process, named "tidal pumping" is typical of macrotidal estuaries and can be explained by the strong tidal current asymmetry due to estuary frictional effects. Tidal wave displays a short sharp rise with high current velocities and a longer and slower fall with low current velocities. Thus, the current velocities asymmetry induces also an asymmetry on the sediment deposition and erosion budget during a tidal cycle; during this period, the mud bed acts as a suspended matter buffer leading to an upstream transport of the resulting material. During spring tides (up to $8 \mathrm{~m}$ ) and low river flows, ebb currents are not able to drain off the fine-grained particles 
brought by the flood currents and deposited during the slack tide period. Nevertheless, some part of the deposited mud layer may survive [7].Field evidence of this process was brought by high frequency flow rate and suspended load measurements across river transversal sections [8]. At La Bouille (kp 260), during spring tides, residual particulate discharge has been found to be oriented upstream (up to 64 tons.tide ${ }^{-1}$ ). This process is locally favoured by meanders (inside parts) and sand banks.

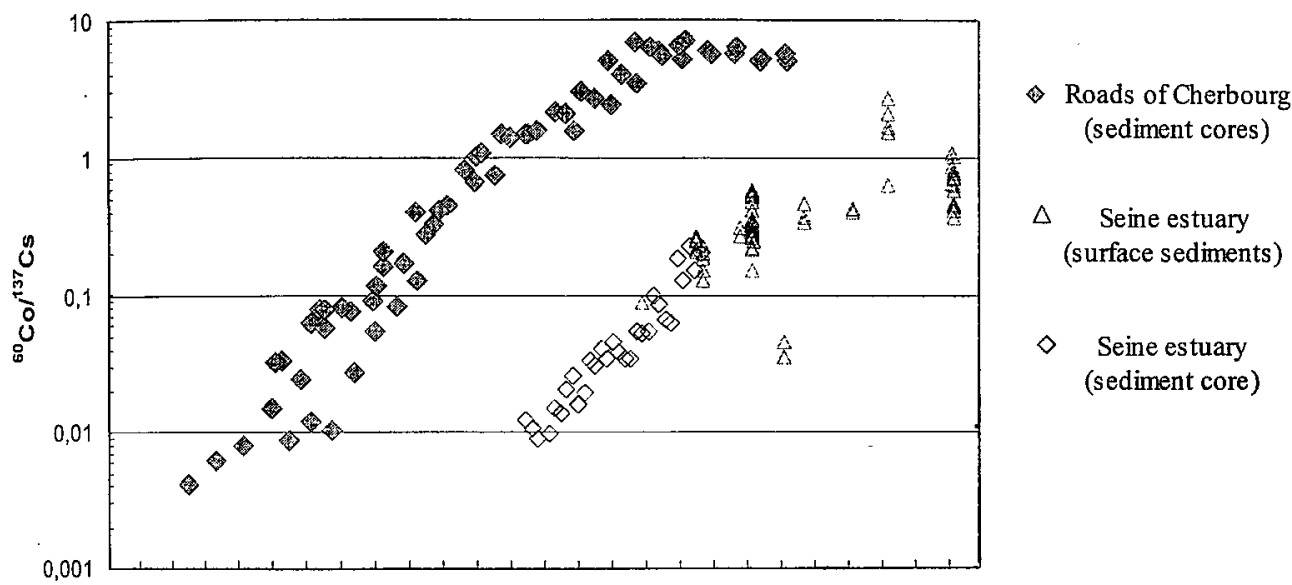

7576777879808182838485868788899091929394959697989900

Time (years)

Figure 4. Evolution of ${ }^{60} \mathrm{Co} /{ }^{137} \mathrm{Cs}$ ratios (normalized at 01/01/2000) in sediments collected in the Channel versus time (years) as observed in surface sediments from the Seine estuary (Section $\mathrm{kp} 350$ to 400 ; see figure 1) and recorded in sediment cores collected in the Roads of Cherbourg between 1984 and 1996, and in the Seine mouth (Le Havre; kp 365) in 1992.

\section{CONCLUSION}

The use of ${ }^{60} \mathrm{Co}$ as a marker of sediment particles originating from the Central Channel shows that these particles are liable to progress far upstream (more than $100 \mathrm{~km}$ ) from the river mouth. This paradoxical observation is the consequence of the "tidal pumping", as previously discussed. The upstream progression of this transient signal, with an average velocity of $c a 10 \mathrm{~km}^{-1} \mathrm{y}^{-1}$, documented between 1900 and 2000, is consistent with the sediment records derived from cores collected in both the river mouth and in the Central Channel. It is still going on and will be followed up in the forthcoming years.

\section{Acknowledgements}

Part of this work was carried out in the frame of the SEINE AVAL I Programme and of the DISSED project supported by IPSN. 


\section{References}

[1] Boust D., Cont. Shelf Res.,19, (1999). 1959-1975.[2] Pally M. and Lambrechts A., Bilan radioécologique décennal du Cnetre nucléaire de production d'électricité de Nogent-sur-Seine1997 - Rapport SERE 98/022 (1998).

[3] Boust D. Programme Scientifique Seine Aval ; Thème Dynamique des Contaminants. Rapport SERE 97/008 (1996).

[4] Boust D. Programme scientifique Seine-Aval.Thème hydrodynamique et transport sédimentaire. Rapport SERE 98/020 (1998).

[5] Boust D., Rozet M., Solier L., Dupont J.P., Lafite R. et A. Ficht Programme scientifique SeineAval. Thème hydrodynamique et transport sédimentaire Rapport DPRE/SERNAT/99-12 (1999).

[6] Boust D., Colin C., Leclerc G. and Baron Y., Radioprotection, 32, Spec. Issue "Radionuclides in the Oceans",(1997) 123-128.

[7] Dyer K.R., Coastal and Estuarine Sediment Dynamics (J. Wiley, Chichester, 1986).

[8] Guézennec L., Lafite R., Dupont J.P., Meyer R. and Boust D., Estuaries 22-3a, (1999) 717-727. 